\title{
REPRESENTING ALTERITY IN A POST-COLONIAL CONTEXT: LÍDIA JORGE'S A COSTA DOS MURMÚRIOS AND ITS ENGLISH AND FRENCH TRANSLATIONS
}

\author{
Dominique Faria* \\ Universidade dos Açores/Universidade de Lisboa
}

\begin{abstract}
This article explores two translations of Lídia Jorge's $A$ costa dos murmúrios (1988), published in France (1989) and in the United States (1995). Translated from a peripheral language into central languages and dominant cultural systems, this novel about the Portuguese colonial war in Africa had contrasting receptions in those countries, which point to different approaches to its translation. This study sets out to identify the main agents and external factors involved in the translation process and to determine the role that issues of patronage, the national translation tradition and the national history of both receiving cultures play in it. With these questions in mind, the focus will then turn to the way the colonized people and their culture are represented in the novel, to verify whether or not there was a tendency, in translating, to replace non-Western cultural references with more widespread forms of representation.
\end{abstract}

Keywords: Lídia Jorge. Post-colonialism. Translation. Portuguese Literature. Colonial War.

* Dominique Faria: PhD in contemporary French Literature (2008) from the University of the Azores, Portugal. MA in French Literature (1998) and BA in Modern Language and Literature (French and English), both from the University of Lisbon, Portugal. She is an Assistant Professor of the Department of Modern Languages and Literature at the University of the Azores, Portugal, and also a member of the Centre for Comparative Studies of the University of Lisbon, Portugal. Ponta Delgada, Região Autônoma dos Açores, Portugal. E-mail: dominique.ar.faria@gmail.com 


\title{
A REPRESENTAÇÃO DA ALTERIDADE NUM CONTEXTO PÓS-COLONIAL: A COSTA DOS MURMÚRIOS DE LÍDIA JORGE EM TRADUÇÃO INGLESA E FRANCESA
}

\begin{abstract}
Resumo: O presente artigo analisa duas traduções de $A$ costa dos murmúrios (1988) de Lídia Jorge, uma publicada em França (1989) e outra nos Estados Unidos da América (1995). Traduzido de uma língua periférica para línguas centrais e sistemas culturais dominantes, o romance sobre a guerra colonial portuguesa em África teve receções contrastantes naqueles países, as quais revelam diferentes abordagens à tradução. Este estudo visa identificar os principais agentes e fatores externos envolvidos no processo de tradução, assim como determinar o papel que questões como mecenato, tradição nacional de tradução e história nacional de ambas as culturas recetoras desempenham nesse processo. Com base nesta discussão, refletir-se-á então sobre o modo como o povo colonizado e a sua cultura são representados no romance, de forma a verificar se existe ou não uma tendência, ao traduzir, para substituir referências estranhas à cultura ocidental por formas de representação mais generalizadas.

Palavras-chave: Lídia Jorge. Pós-colonialismo. Tradução. Literatura Portuguesa. Guerra Colonial
\end{abstract}

\section{Telling the colonial war while unveiling the pitfalls of representing alterity}

Lídia Jorge's novel A Costa dos Murmúrios posits itself as a project to reinstate the events of colonial war repressed by Portuguese history, in a process described by Eduardo Lourenço $(2000,46)$ as an unprecedented collective unconsciousness. The story takes place in Mozambique, in the late 1960s and early 1970s, and is told by Eva Lopo, the wife of a Portuguese army officer. As Santos $(1989,67)$ emphasizes, it ruthlessly uncovers imperialism, colonialism, war, oppression, violence, and sexism. In a complex, polyphonic, layered text, evoking specific historical events ${ }^{1}$ while

\footnotetext{
${ }^{1}$ One clearly identifies the so called operation "Nó Górdio" (1970), which took place in the Makonde territory of Cabo Delgado, and the Wiryiamu massacre (1972), evoked by the photographs described by Eva Lopo.
} 
simultaneously questioning the filters engaged in the telling, ${ }^{2}$ Lídia Jorge acknowledges the impossibility of retrieving the truth of what happened. Instead, she carefully builds a relentlessly ironic, sarcastic and inconclusive account of the end of the Portuguese empire.

Despite the abundance of published studies on this novel, most of which highlight its narrative devices or focus on how it tells the colonial war, seldom has the way it depicts alterity been acknowledged. In current theoretical discourse, as Shameem Black sums up, "[r]epresenting alterity is frequently understood as an act of discursive domination that replicates, in literary form, the violent operations of political, economic, and social inequality (Black 2010, 19). This could be even truer in A Costa dos Murmúrios, since it is a book about authority and domination, written in the language of the colonizer, about the relationship between colonizer and colonized, and the sensitive topic of the colonial war. ${ }^{3}$ However, Lídia Jorge seems to embrace the widespread contemporary mistrust of the possibility of representing otherness in post-colonial contexts. To avoid the typical pitfalls of such a task - namely telling the story from one single standpoint (that of the colonized or of the colonizer) or even adhering to stereotypes which tend, as Bhabha $(2012,88)$ puts it, to "glid[e] above reality, licensing disgust, disavowal, domination" - the Portuguese author tells the story through the viewpoint of a woman ${ }^{4}$. Because of her gender, this character is located inbetween the two worlds, that of the colonizer (because she is white, Portuguese, and the wife of a soldier) and that of

${ }^{2}$ The novel starts off by a short narrative (called "Os gafanhotos" ["The Locusts"]) from a fictional author whose identity is never disclosed and which tells some events the main story will review, rethink and discuss.

\footnotetext{
${ }^{3}$ The Portuguese Colonial war lasted between 1961 and 1974 and opposed Portugal's military forces and the nationalist movements in its African colonies, mostly Angola, Mozambique and the Portuguese Guinea. It came to an end with the 1974 coup d'état, in Portugal, led by the military, who protested against the war's length and its financial costs, as well as the lack of democracy.
}

${ }^{4}$ This seems to be a common feature of post-colonial Portuguese fictions (see Helena Kaufman 1991, 118): the attempt at understanding the others is primarily made by women. 
the colonized (a female in a male dominated world, who lacks patriotic fervour and is treated with contempt). Moreover, in a Penelope-like attitude, Eva Lopo tells and simultaneously questions the veracity of what she is telling, regularly drawing the reader's attention to the role played by words in shaping reality, thus developing a "criticism of language and representation" (Medeiros $2009,217)$. So much so that, when her weaving must finally come to an end, the last words of the novel tend to erase what had been said: "'Little by little the words detach themselves from the objects they designate, then the sounds separate from the words, and of the sounds only murmurs remain, the final stage before erasure,' said Eva Lopo, laughing. Handing back, annulling 'The Locusts'" (Jorge 1995, 274).

Because "a choice of language is a choice of identity" (Durring $1995,126)$, the purpose of the present article is to study the way that alterity - the colonized and their culture - are represented in Lídia Jorge's novel and to compare it with its English and French translations. The fact that Western cultures have a tendency to translate texts about non-Western cultures according to their own conceptual and textual grids (cf. Lefevere 1999), and that the more central a literature is the more it will tend to do so (cf. Even Zohar 2000), has been thoroughly discussed in translation theory in the last decades. This study aims at verifying to what extent these cases confirm or contradict this tendency and at identifying the main agents and external factors involved in the process.

\section{Translating a text about the Portuguese colonial war in Africa: issues of power, ideology and reception}

A Costa dos Murmúrios is a Portuguese novel which has been translated into dominant linguistic and cultural systems, that of the United States and of France. With regard to translation flows, Portuguese is often described as a peripheral language, with only 1 to $3 \%$ of the books in the international market being translated 
from this language (Sapiro 2008). It is therefore quite difficult for a Portuguese text to penetrate the international book market, all the more so when its main subject is specific to Portuguese history and culture and it strives to represent ethnic minorities as is the case with Jorge's novel. On the other hand, English is considered a hypercentral language and French a central one, with corresponding percentages of books translated from these languages of $50 \%$ and $12 \%$ respectively (Sapiro 2008). ${ }^{5}$ The specific place ascribed to an author in the national literary canon also determines the choice of texts to be translated and the way they are translated. In Lídia Jorge's case, she was still a young author at the time, having published four novels when the French translation was produced, and six when the English version was made available. ${ }^{6}$

Despite these contextual constrains, the French version Le Rivage des murmures - was published in the Éditions A.M. Métailié, a young publishing house at the time (founded in 1979). It has specialized mostly in translated literature in an attempt, as stated on its web page, to show the diversity of literature beyond the "dominant cultures". ${ }^{7}$ Jorge's novel was included in a collection called "Bibliothèque Portugaise" [Portuguese Library], alongside those of Agustina Bessa-Luís, Jorge de Sena and Vergílio Ferreira, all renowned contemporary Portuguese authors. The back cover of the French translation of Lídia Jorge's novel states this was the second of her works to be published in France. Jorge's novel was presumably perceived in France as a typical example of quality Portuguese contemporary literature, despite the author's short career. Moreover, this translation was published one year after the book was launched in Portugal (in 1989), with the support of the French Centre National des Lettres and the Portuguese Fundação

\footnotetext{
${ }^{5}$ For a glimpse of the European context see Wischenbart (2008, 2009, 2010).

${ }^{6}$ The most significant awards to her work did not come before 1998, when she received four prizes for the same novel, $O$ Vale da Paixão [The Painter of Birds], a turning point in her career.
}

${ }^{7}$ See http://editions-metailie.com/la-maison/. 
Calouste Gulbenkian. Both these institutions grant subsidies to publishing houses and translators for publishing translated literature. This shows there was an institutional interest on the part of both countries to publish Lídia Jorge's work in France.

The translator was Geneviève Leibrich, who has since become famous for translating prominent Portuguese authors such as the Nobel prize winner José Saramago. Leibrich does not discuss her translation options: the book does not contain a translator's preface and, although there are some translation notes, ${ }^{8}$ these do not mention translation issues. The abstract on the back cover fosters the idea that this is a simple story told by a woman about the end of colonialism: "L'impitoyable portrait de la guerre et de la peur vu par une femme qui aurait voulu crier ce qui n'était que murmures" [The ruthless portrayal of war and fear, seen by a woman who would have wanted to shout what were but whispers]. This naive presentation of the text is even more surprising if we take into account that French literature has a long history of subverting literary traditions (the 1980s were the aftermath of the "Nouveau Roman"). The French (translator, editor, reader) would quite possibly be sensitive to the formal innovation and complexity of this novel. Instead, the novel was publicized in France on the basis of its subject matter, and regarded as a simple fictional text about the colonial war in Africa. ${ }^{9}$

The English version - The Murmuring Coast - was published by the University of Minnesota Press, in 1995. It was part of a series called "Emergent Literatures", described as including "works of fiction that have been ignored or excluded because of their difference

\footnotetext{
${ }^{8}$ In a total of eleven translator's notes, six are used to signal foreign (French and English) words in the Portuguese version, three to explain some rather obscure cultural references of Portuguese history without which the passages would be hard to decode, and two to explain the meaning of two Portuguese words referred to in the text ("Deus" and "Saudade").

${ }^{9}$ It is tempting to co-relate the translator's silence about translation issues with this perception of the text: commenting on translation options would foreground the text as a construct, whereas keeping them discrete is more likely to foster what Schaeffer $(1999,180)$ calls "fictional immersion", through which readers forget reality and imagine they are living the adventures they are reading about.
} 
from established models of literature". It also comprised works by Hélène Cixous, Elias Khoury, Manuel Rui, José Revueltas, and Adrienne Kenney. The back cover clearly states this was the first translation into English of any of Lídia Jorge's works. This alone shows how the novel was perceived in the United States: as part of what we could call world literature, placed in the specific group of young authors and envisaged as rebelling against literary tradition.

The translators, Natália Costa, at the time a $\mathrm{PhD}$ student in contemporary Portuguese literature at the University of Minnesota, and Ronald W. Sousa, a professor of Portuguese literature at the University of Illinois, are both specialized in Portuguese literature. This project was not driven by a search for profit, but by the desire to counter the uneven power relations between peripheral and central literatures. This context explains why these two translators, who do not use translation notes, were given the opportunity to write a "Translator's Preface". In it, they not only explain some translation options and discuss the main difficulties in translating this novel, but also give the American reader guidelines for reading the novel. They underline the novel's intricate structure, stating it is "a critique of the language practices justificatory of [...] colonialism effected through their narrative dismantling" rather than a "critique of Portuguese colonialism effected through a complexly presented but 'realistic' portrayal" (Jorge 1995, v). The translators also predict that the translated text will "represent a cultural challenge to English-speaking readers" (vii), due to the lack of "close parallels" to the phenomena it depicts in the Englishspeaking world.

Both these translations were published in small publishing houses, moved by ideological rather than commercial reasons. Patronage was therefore of the uttermost importance. Yet, there seem to have been significant differences in the way the text was perceived in the two countries. The French presented it as a straightforward fiction about colonial war, written by an acclaimed Portuguese author. National history and patronage probably influenced such an interpretation. In fact, this particular subject 
is likely to resonate with the French readership, since France has a similar, complicated history of war with its former colonies, Algeria in particular. Also, there was a political - rather than an academic - purpose in publishing this translation, both on the part of Portuguese and of French institutions, who acted as patrons to this translation.

In the United States, on the other hand, Lídia Jorge was perceived as a young author, writing unconventional, provocative texts, of which this novel was an example. The academic context in which the translation was made and published and the status of the translators (who specialized in Portuguese literature) might explain this perception of the novel, as well as the decision to highlight the fact that it is a translation (through its preface). Also, for historical reasons, the subject of colonial war is less likely to elicit such a direct emotional response from the American readers as it did for the French ones.

\section{Colonizers and colonized: for sensitive subjects, sensitive words}

In $A$ Costa dos Murmúrios, violence is not represented through war scenes, ${ }^{10}$ but rather through language choices. A group which has a specific vocabulary is that of the army officers. They are often torn between the need to fulfil their duty and a feeling of guilt. ${ }^{11}$ This manifests itself in their vocabulary options: they protect themselves from the atrocities of war by hiding behind violent, biased language and slang. One of the most obvious examples is the

\footnotetext{
${ }^{10}$ The closest we can find is a description of photographs documenting some massacres.

${ }^{11}$ This is often manifested through language choices. Moutinho $(2008,82)$ shows, for instance, how an apparently accidental shift of adjective - "stupid" is first used to describe the soldiers and their families sleeping and is subsequently applied to the Africans when they are the victims of a massive poisoning with methyl alcohol - "signifies the transference of feelings of guilt (very likely unconscious) and the persistence of self-doubts in the mind of the military".
} 
use the soldiers make of the verb "lerpar" (slang for "to die") instead of "morrer" ("to die" in standard Portuguese), when referring to the death of Mozambicans. The verb occurs four times in the novel (Jorge 1988, 14, 34, 39). In the English version it is translated as "to die" (Jorge 1995, 16), "to get screwed" (43), "to happen" (43), and "to buy it" (50). In French, it was translated as "crever" (Jorge 1989, 24, 49), "passer l'arme à gauche” (49), “casser sa pipe" (55), all of which belong to a more colloquial language level than "mourrir", but still refer to the same act. Instead, the English version diminishes the idea of death by replacing it with phrases (except for the first case) which do not refer specifically to death. What is more striking, however, is that both translations replace one single word, recurrently used by the author, with several different ones. This becomes particularly obvious if we look at the following example:

'mas o sacana do black que fazia aqueles cocktails também lerpou'. 'Como é que lerpou?' (Jorge 1988, 34)

'mais cette fripouille de black qui fabriquait ces cocktails fantastiques a lui aussi passé l'arme à gauche.' 'Et de quoi a-t-il crevé?' (Jorge 1989, 49)

'but the damned black that used to make those cocktails was one of those who got screwed.' 'Do you know how it happened?' (Jorge 1995, 43)

This passage shows that repeating the same word is not an accident, it entails crucial implications: here the army officer, Eva Lopo's husband, repeats the word used by his captain, whom he admires. Sharing the same vocabulary entails complicity and fosters the so called "esprit de corps". This effect is lost in the translation.

One other set of crucial words is that of the terms used to designate people through their skin colour. Hence, in Portuguese 
two different words are used to designate Africans through their skin colour: "preto" and "negro". "Preto" had a very negative connotation in the Portuguese colonies before 1974, whereas "negro" was considered a more neutral word. In $A$ Costa dos Murmúrios, three words are employed: "negro", "preto", and "black". "Negro" is the most frequently used one (it occurs 57 times), generally by the narrator and her journalist friend. The soldiers prefer "preto" (used 11 times) and "black" (29 times in the novel). "Black" stands out in the Portuguese text both because it is a foreign word and because it is always in italics. It is probably a sign of the close relationship between the Portuguese regime and the South-African one.

In the English translation, the word "black" remains unchanged. The translators concede, in their preface to the translation, that part of the information got lost (Jorge 1995, vi). "Negro" and "preto", on the other hand, were translated either by "black man" or "black". The translators could have used the word "nigger" for "preto" and "black" for "negro", thus preserving a distinction between the two ways of addressing the same reality, as Lídia Jorge did. However, "nigger" is much more offensive and racist than "preto", a word which does not produce in the Portuguese speakers such passionate reactions as the often called " $n$ word" among Americans. In the English version there is therefore no distinction between the different designations and, as a consequence, racism becomes less obvious. In the French version, "black" is kept in English and in italics ("les blacks"), which creates the same effect as the Portuguese text. "Negro" and "preto", however, are not evenly translated. The translator uses "noir" (which does not have a negative connotation) and "nègre" (which is considered insulting) indifferently, as can be seen in these two expressions, taken from the same paragraph: "Caçador de pretos" (Jorge 1988, 178) - "chasseur de Nègres" (Jorge 1989, 229) - and "Matador de pretos" (Jorge 1988, 178) - “Tueur de Noirs" (Jorge 1989, 230).

These two groups of examples show there is a tendency, in the English translation, to tone down sensitive topics such as death and 
racism. The same cannot be said of the French translation, where an effort was made to keep the references to these subjects. It is clear, however, that these translators do not pay much attention to the role played by the recurring use of the same word(s) throughout the text.

\section{Representing alterity via linguistic difference}

Lídia Jorge often embeds in her text words referring to specific traits of the Mozambican culture which are not generally known to the Portuguese reader and for which she provides no explanation. By doing so, this author "confront[s] two radically different languages and cultural systems brought together by historical circumstances characterized by unequal power relations" (Bandia 2014, 31). Although the meaning of some words can be inferred from the context, others demand some research on the part of the reader, who is invited to make an effort in order to get to know the other's culture. It is therefore a technique of defamiliarization which deliberately renders the act of reading more difficult. The explanation for this choice seems to be a twofold one. First and foremost, in a novel which embodies the limits of representation - the impossibility of fiction, memory and History to perceive and convey the truth - and where Africans are not given a chance to express themselves, these lexical items are pieces of the real world - they actually exist - which remain untouched by fictional devices. A second explanation could be drawn from the following excerpt: "The pilot watered down his drink, explaining how difficult it had been to translate the word 'panacea' into Makonde, a language that had only words like fire, water, gourd, mouse, hut..." (Jorge 1995, 14). ${ }^{12}$ Using African words is therefore a way to legitimize low status minority languages, but also to symbolically pinpoint alterity and to signal specific aspects of the Mozambican culture.

12 "O piloto retraçava o aperitivo, explicando como fora difícil traduzir para maconde a palavra panaceia, uma língua que só tinha vocábulos como fogo, água, cabaça, rato, chitala..." (Jorge 1988, 104). 
In this novel, there are almost no descriptions of landscapes, social habits or even of the indigenous people. Africans are rarely identified through their names and their words are seldom put into direct speech. The white Portuguese in the novel are unable to think of Africans as individuals and the author's approach shows just that (what remains is a void, a silence). They are generally designated either through their skin colour, as seen above, or through their function. Hence the use of the Mozambican Portuguese word "mainato", and its feminine version "mainata", which designates the African male and female servants who worked in Portuguese homes during colonial times. This word occurs 71 times in the text, which shows it plays a crucial role in it. The Portuguese characters in the novel treat their "mainatos" as less intelligent, somehow childish creatures. Still, the "mainatos" remain the only autochthonous people with whom they develop strong emotional ties. ${ }^{13}$ The word does not, therefore, hold an entirely negative connotation.

In the English translation, "mainata" was replaced with "maid" and "mainato" with "boy" (sometimes in italics), "houseboy" and "washboy". In French "mainata" is translated as "bonne", "mainato" as "boy" (with no italics). Both "maid" and "bonne" refer to Western contexts where the word is used to designate female servants. "Boy", in contrast, refers to a colonial context. It was used both in English and French to designate young natives who became servants in the ex-colonies, although it bears a more negative connotation in English than it does in French. ${ }^{14}$

The text explores the differences between these servants and the European ones. This becomes particularly visible as regards the "mainatos" of the aforementioned captain of Eva Lopo's husband. In fact, his servants change their names when they start working for him, taking on names like "Mateus Rosé" and "Adão Terras

\footnotetext{
${ }^{13}$ Several episodes throughout the novel show that the wives of the Portuguese soldiers fear for the lives of their servants and are devastated when they die.

${ }^{14}$ According to the Oxford English Dictionary, "Boy" designates a male servant or a slave and it is considered offensive in English, whereas the French dictionary Larousse simply defines the word as "jeune serviteur indigene, dans les pays colonisés".
} 
Altas"15 (both names of Portuguese wines), or "Seven-Up". As for his female servant, she is called Odília, a regular Portuguese name for a woman. She does, nonetheless, undergo a process of forced (and unsuccessful) acculturation: in an attempt to tone down the unsettling presence of alterity in their home, the captain's wife forces Odília to put on a European uniform, which does not fit her (she is often described as looking clumsy in those clothes and shoes). In the following excerpt the differences between a "mainata" and a "criada", the Portuguese word for a female servant, becomes clearer:

Ao toque da sineta de prata, a mainata apareceu, calçada e de soquete, vestida de criada europeia, embora mantendo o lenço na cabeça. (Jorge 1988, 72)

$\mathrm{Au}$ tintement de la clochette d'argent la bonne apparut, chaussée, portant des socquettes, vêtue en soubrette européenne, mais la tête toujours entortillée dans le même mouchoir de tête. (Jorge 1989, 97-98)

At the sound of the silver bell the maid appeared, wearing shoes and crew socks, dressed like a European maid, although she still had her head wrapped in a scarf. (Jorge 1995, 94)

This example shows how words are carefully chosen in this novel: for the author there is a difference between a "criada" and a "mainata". The English version makes no such distinction, since the same word is used for both cases. As for the French one, "soubrette" designates a coquettish maid, most likely seen in operas and comedies. This significantly alters the message, since

15 "Adão" means Adam, which could be interpreted as a religious reference. However, given the other names adopted by the servants, it seems more plausible that "Adão" results from a misunderstanding of the way the wine "Terras Altas" is usually referred to: as "vinho do Dão - Terras Altas" ("Dão" designates the Portuguese regions where the wine is produced). 
the African female servants - and Odília, to whom the passage refers - are not at all coquettish, on the contrary, they seem very awkward in that European uniform.

Another important word in this novel is "matacanha" (Jorge $1988,60,148,191)$. The word is used in Mozambique to designate a parasitic flea, often found in tropical climates. In the novel, it plays a symbolic role. First the "frightened" Makonde are described as having them under their fingernails as they fight against the Portuguese soldiers. By the end of the novel, however, the Portuguese soldiers (and, more specifically, Eva Lopo's husband) have them under their own nails as they return, defeated, from the last battle. In the French version, "matacanha" is always translated by "chique" (Jorge 1989, 82, 191, 245), which is the French word for this precise parasite. In the English version, however, the Makonde are said to have "dirt" under their fingernails (Jorge 1995, 78), later on the Portuguese soldiers endured a "terrible flea infestation" (193), and at the end of the novel Eva Lopo's husband has "slivers" (250) under his fingernails. The English translation therefore undermines the importance of this parasite in the novel.

The next two words do not play such a key role in the text. They are, however, words used in Mozambique, which are unknown to the Portuguese reader. "Chitala" (Jorge 1988, 86, 104 ) is a Makonde word which refers to a house where men have assemblies. It is translated into French as "case" (Jorge 1989, 116), which designates a hut in Africa, and "toit de chaume" (136), which refers to a straw roof. In English it is replaced by the word "hut" (Jorge 1995, 114) and "cane hut" (135), all of which are more general and universal. The second word is "capulana" (Jorge 1988, 43), a sort of colourful scarf Mozambican women wear around their waists. It occurs only once in the novel, in a very emblematic situation: during a massacre, an African dead man is carried on the streets, covered by a "capulana". The French translator uses "pagne" (Jorge 1989, 62), which refers to the same kind of African textile in French. The American translators opted for "sheets" (Jorge 1995, 56), which inscribes this typical African 
(and offhand) situation in a Western framework, where dead bodies are generally covered by sheets.

Jiri Levý envisages translation as a decision process, whereby the translators resort to what the author calls the "minimax strategy" (Levý 2000, 156), choosing to devote their time and effort to keeping only the features of the text they consider crucial. In translating $A$ Costa dos Murmúrios, these translators decided not to keep the Mozambican words used by Lídia Jorge. They followed what Tymoczko identifies as a generalized human tendency to "assimilate the unknown to the closest known pattern" which results in a translation "shaped by the contours of the receiving culture" (Tymoczko 1999, 50). This dramatically changes the reading experience, for the French and American readers are provided with a domesticated text, easily decoded. Also, there is a stronger tendency in the English translation to erase specific cultural references and to replace them with more common, Western ones than in the French version. This somehow confirms what is claimed in theoretical discourses about translation, namely those which highlight the tendency to domestication that is prevalent in the United States (Venuti 2001).

\section{Translating otherness in a post-colonial context}

Several external factors interfered in the translation of this novel into French and English: issues of patronage, reception, national translation traditions and national history. Hence, when comparing the two translations, the French one is more prone to keeping references to racism, violence and even to African cultural traces, than the English one. In fact, the American version of this novel tends to tone down racism and violence and to erase specific aspects of the Mozambican culture, replacing them with more neutral forms of representation, thus undermining the presence of alterity throughout the text. 
Moreover, although both translations were undertaken for ideological reasons rather than mainly for profit, the French translation was promoted and supported by political institutions from both countries, whereas the American one was led by a scholarly institution. Also, whereas the typical reader of a book published by the University of Minnesota Press is a university student, conceivably more sensitive to the literary qualities of the text, the Éditions A.M. Métailié addresses a more general public, most probably interested in finding a good story. This probably influenced the way this Portuguese novel was perceived by the translators and the publishing houses: as innovative in the way it dismantles literary tradition, in the United States, and as a striking story about the colonial war, in France. Such perceptions may have been explicitly dictated by the publishing houses or assumed by the translators themselves. The differences between both nations' historical backgrounds may also have contributed to such discrepancies. In fact, although the American readership would be likely to identify with issues such as racism and social inequality, the French receiving audience, because it belongs to a former colonizing country, would probably respond more directly to the subject of colonial war.

Two specific traits of Lídia Jorge's writing disappear from both translations. The first one is the inclusion of foreign words, belonging either to the Mozambican Portuguese or to other minority local languages, in the Portuguese text. This causes the reading experience to radically change: the French and English language readers are not required to make the same effort as the Portuguese reader does to understand the text. The foreign readers are provided with a more familiar text. The second aspect is the tendency that Jorge has to create what Antoine Berman (2000, 292-293) calls "underlying networks of signification", by regularly repeating the same sets of words throughout the text. Often, translators opted for a wider variety of lexical items to replace one single word, which causes this second layer of reading to disappear from the translated version. In Jorge's writing, these regularly used words often tell more than the text explicitly states. 
In sum, these two versions of Lídia Jorge's novel were published around the same time, into central languages; the text was nevertheless perceived differently in the two national contexts by the publishing houses and its translators (and presumably its readers). Whereas the French version of the text was assumed to be a story on colonialism and therefore tended to keep specific cultural references, the English (American) one showed a tendency to evade more specific and sensitive words and topics.

The work of the translator always depends on a set of external factors which, when taken into account, greatly contribute to the study of translation. This becomes even more pressing in cases where issues such as the representation of autochthonous peoples or the relationship between (former) coloniser and colonized are at stake.

\section{References}

Bandia, Paul. Translation as Reparation. Writing and Translation in Postcolonial Africa. London \& New York: Routledge, 2014.

Bhabha, Homi. The Location of Culture. London: Routledge, 2012.

Berman, Antoine. "Translation and the Trials of the Foreign". The Translation Studies Reader. Ed. Lawrence Venuti. London \& New York: Routledge (2000): 284-297.

Black, Shameem. Fiction across Borders. Imagining the Lives of Others in Late Twentieth-century Novels. New York: Columbia University Press, 2010.

Durring, Simon. "Postmodernism or Post-colonialism Today." The Post-colonial Studies Reader. Eds. Ashcroft, B., Griffiths, G., Tiffin, H. London, NY: Routledge (1995): 125-129. 
Even-Zohar, Itamar. "The Position of Translated Literature within the Literary Polysystem." The Translation Studies Reader. Ed. Lawrence Venuti. London \& New York: Routledge (2000): 192-197.

Jorge, Lídia. A Costa dos Murmúrios. Lisboa: Publicações Dom Quixote, 1988.

. Le Rivage des Murmures. Trans. Geneviève Leibrich. Paris: Éditions A.M. Métailié, 1989.

. The Murmuring Coast. Trans. Natália Costa and Ronald W. Sousa. Minneapolis: University of Minnesota Press, 1995.

Kaufman, Helena. Ficção Histórica Portuguesa do Pós-revolução. Wisconsin-Madison: University of Wisconsin-Madison, 1991.

Lefevere, André. "Composing the other". Post-Colonial translation: Theory and Practice. Eds. Susan Bassnett, and Harish Trivedi. London \& New York: Routledge (1999): 75-94.

Levý, Jiri. "Translation as a Decision Process." The translation studies reader. Ed. Lawrence Venuti. London \& New York: Routledge (2000): 148-159.

Lourenço, Eduardo. O Labirinto da Saudade, Psicanálise Mítica do Destino Português. Lisboa: Gradiva, 2000.

Medeiros, Paulo. "Hauntings: Memory, Fiction, and the Portuguese Colonial Wars." The Politics of War Commemorating War. Eds. Ashplant T.G., Dawson G. and Roper M. London: Routledge (2009): 201-221.

Moutinho, Isabel. The Colonial Wars in Contemporary Portuguese Fiction. Rochester, NY: Tamesis, 2008.

Santos, Maria Irene Ramalho de Sousa. "Bondoso caos: A Costa dos Murmúrios de Lídia Jorge.” Colóquio Letras 107 (1989): 64-67. 
Sapiro, Gisèle (dir.). Translatio. Le Marché de la traduction en France à l'heure de la mondialisation. Paris: CNRS Éditions, 2008.

Schaeffer, Jean-Marie. Pourquoi la Fiction? Paris: Seuil, 1999.

Tymoczko, Maria. Translation in a Postcolonial context. London \& New York: Routledge, 1999.

Venuti, Lawrence. "American Tradition.” Routledge Encyclopedia of Translation Studies. Ed. Baker Mona London \& New York: Routledge (2001): 305-3016.

Wischenbart, Rüdiger. Diversity Report 2008. An overview and analysis of translation statistics across Europe: facts, tends, patterns. 2008. Available at: < http:// www.wischenbart.com/diversity/report/Diversity \%20Report_prel-final_02. pdf $>$.

Wischenbart, Rüdiger; Kovac, Miha. Diversity report 2009. Cultural diversity in translations in books: mapping fiction authors across Europe. 2009. Available at: $<$ http://www.wischenbart.com/diversity/report/Diversity_Report_2009_final. pdf $>$.

. Diversity report 2010. Literary translation in current European book markets. An analysis of author, languages, and flows. 2010. Available at: < http:// www.wischenbart.com/diversity/report/Diversity-Report_2010.pdf > .

Recebido em: 05/07/2016

Aceito em: 17/09/2016

Publicado em janeiro de 2017 